\title{
ANALISIS ISI DALAM PENELITIAN PEMBELAJARAN BAHASA DAN SASTRA
}

\author{
Sumarno \\ sumarno@umko.ac.id \\ Universitas Muhamamdiyah Kotabumi
}

\begin{abstract}
Abtract: Content analysis could be applied widely in language and literature learning. It could be used to (1) describe learning trends, know learning model or pattern, solve learning provlem, access an attitude, value, and school culture values, describe teacher perception, and describe learning management idea. In addition, it could be used to describe for language and literature research, such as discource analysis, describing literature aspects, literature values, and reader perception to the literature. To optimalize the analysis proccess, researchers cound use their analysis skill to arrange communication content phenomenom to be social phenomenom which read generally.
\end{abstract}

Keywords: Content Analysis, Language Learning and Literature Research

\begin{abstract}
Abstrak: Analisis isi (content analysis) dapat diaplikasikan secara luas dalam pembelajaran bahasa dan sastra di sekolah, misalnya untuk: mendeskripsikan kecenderungan pembelajaran (trends); mengetahui pola/model pembelajaran; keunikan sekolah/ guru mengatasi masalah; menduga sikap, nilai dan pola budaya sekolah; mendeskripsikan persepsi guru; dan mendeskripsikan gagasan pengelolaan pembelajaran. Selain itu dapat pula digunakan untuk penelitian bahasa dan sastra, seperti analisis wacana kritis, mendeskripsikan unsur-unsur karya sastra, nilai-nilai karya sastra, dan persepsi pembaca terhadap karya sastra. Analisis isi memerlukan peneliti yang memiliki dan dapat memanfaatkan ketajaman analisisnya untuk merajut fenomena isi komunikasi menjadi fenomena sosial yang terbaca secara umum.
\end{abstract}

Kata kunci: Analisis Isi, Penelitian Pembelajaran Bahasa dan Sastra

\section{Pendahuluan}

Sebenarnya analisis isi (content analysis) sebagai sebuah istilah umurnya sudah sangat tua, mungkin setua umur manusia, tetapi sebagai suatu metode penelitian tidak setua pemakaiannya sebagai istilah. Pemanfaatan analisis isi dalam kehidupan sehari-hari tampak dalam kegiatan komunikasi antarmanusia. Dalam kegiatan komunikasi masing-masing yang terlibat melakukan analisis makna (isi) ujaran mitra tuturnya. Bahkan, Adam, manusia pertama yang Allah ciptakan juga telah melakukan analisis isi kalam Allah. Hanya saja Adam melakukan kesalahan dalam menganalisis dan menangkap isi dari Firman Allah itu. Kesalahan analisis itu disebabkan adanya pengaruh dari luar. Dalam konteks hubungan Adam dan Tuhannya kesalahan itu disebabkan Adam tergoda dan memercayai bujuk-rayu iblis. Akan tetapi, apa pun alasannya, sesungguhnya yang utama adalah Adam 
telah melakukan kesalahan dalam menganalisis isi komunikasinya dengan Tuhan. Ide awal menempatkan analisis isi sebagai suatu metode penelitian mula-mula muncul dari Berelson (Bungin, 2006: 218).

Dalam perkembangannya analisis isi terbelah menjadi dua aliran metodologi. Pertama, analisis isi kuantitatif konvensional yang dalam penerapannya sebatas pada melihat kecenderungan isi media terhadap permasalahan tertentu, lalu menguantifikasikan isi media dengan menjumlah frekuensi kemunculan pokok pikiran dari permasalahan tersebut sehingga analisis isi jenis ini hanya mampu menemukenali atau mengi-dentifikasi pesan yang tampak (manifest messages) dan isi media yang dianalisis. Kedua, analisis isi kuatitatif. Analisis isi kualitatif memiliki kecenderungan me-maparkan isi media dilihat dari konteks dan proses dari dokumen-dokumen sumber sehingga hasil yang diperoleh lebih mendalam dan rinci/tertafdil mengenai isi media serta mampu menjelaskan keter-kaitan isi media dengan konteks realitas sosial yang terjadi. Hal itu dikarenakan paradigma kajian analisis isi kualitatif memandang pesan.media sebagai himpunan lambang atau simbol yang mere-presentasikan budaya tertentu dalam lingkup kehidupan masyarakat (Ida, 2006: 187-188).

\section{KONSEP ANALISIS ISI}

Analisisi isi merupakan suatu teknik yang memungkinkan seseorang menguraikan dan memahami perilaku manusia secara tidak langsung, dengan menganalisis komunikasi antara satu manusia dan manusia lainnya, dalam berbagai genre dan ragam bahasa yang digunakan, misalnya melalui buku pelajaran sekolah, berita media massa, esai, novel, cerpen, drama, majalah, artikel, buku petunjuk, lagu, pidato kampanye, iklan, gambar. Isi dari semua bentuk/tipe/jenis komunikasi itu dapat dianalisis karena keyakinan, sikap, nilai, dan pandangan seseorang atau kelompok orang biasanya terungkap dalam tindak komunikasi (Fraenkel dan Wallen,2006:483).

Analisis isi berpangkal pada aksioma bahwa kajian mengenai proses dan isi komunikasi merupakan hal yang mendasari ilmu sosial. Bukankah pembentukan, pengembangan, dan pe-warisan sikap dan perilaku berlangsung melalui sarana komunikasi, khususnya komunikasi verbal. Demikian juga dengan pewarisan nilai-nilai budaya yang dilakukan di sekolah, di tempat kerja, di berbagai lembaga sosial berlangsung melalui komunikasi. Di samping itu, konflik yang timbul dalam ranah sosial dan politik akan dapat diselesaikan dengan komunikasi verbal yang baik yang dilandasi sikap saling memahami situasi dan kondisi masingmasing. 
Analisis isi merupakan kajian ilmiah mengenai isi komunikasi. Secara teknis analisis isi meliputi aktivitas: (1) pengelompokkan simbol/lambang yang dipergunakan dalam komunikasi; (2) penggunaan tolok ukur sebagai dasar pengelompokkan, dan (3) penggunaan suatu teknik analisis sebagai pembuat prediksi (Muhajir,2000:68).

Analisis isi pada dasarnya adalah teknik yang sistematis untuk mengurai isi dan mengolah pesan. Analisis isi dapat juga dipandang sebagai alat untuk mengamati dan mengurai tindak ko-munikasi yang terbuka dari komunikator terpilih (Budd dkk.,1967). Berelson (1952) dan Kerlinger (1986) memandang analisis isi sebagai suatu metode yang dapat dimanfaatkan dalam kajian isi komunikasi secara sistematis, objektif, dan kuantitatif (Wimmer dan Dominick ,2000:135).

Menurut Holsti seperti dikutip Muhajir (2000:71) analisis isi memiliki ciriciri: (1) naskah dioleh dengan peraturan dan langkah-langkah yang sudah dirancang; (2) naskah diolah secara sistematis, penentuan suatu katagori isi isi teks dilakukan berdasarkan peraturan yang telah ditetapkan; (3) proses analisis pesan haruslah memberi kontribusi teoretis/ada relevansi teoretiknya; (4) proses pengkajian dan pembahasan didasarkan pada deskripsi yang dimanifestasikan; dan (5) pemanfaatan teknik kuantitatif.

\section{PRINSIP-PRINSIP ANALISIS ISI}

Menurut Wimmer dan Dominick (2000:135) dalam Subiakto (2006:174) prinsip-prinsip analisis isi adalah sebagai berikut.

1) Prinsip sistematik, yaitu penggunaan prosedur yang sama pada seluruh pesan yang dianalisis. Jadi, tidak diperkenankan hanya menganalisis pesan sesuai dengan minat dan perhatian peneliti, tetapi harus pada semua pesan yang sudah ditentukan dalam populasi dan pemilihan sampel. Jadi, analisis isi tidak sama dengan observasi biasa terhadap isi/pesan.

2) Prinsip objektif, maksudnya ialah bahwa hasil bergantung pada prosedur penelitian, bukan pada peneliti. Salah satunya dengan ketajaman instrumen dan penetapan katagori sehingga orang lain dapat menggunakannya, dengan simpulan yang relatif sama, dengan pesan/isi, sarana, dan prosedur yang sama meskipun berbeda penelitian.

3) Prinsip kuantitatif dilakukan dengan pencatatan nilai bilangan atau kekerapan yang menggambarkan beraneka isi pesan yang didefinisikan. Akan tetapi, prinsip ini juga berarti penerapan hypothetico deductive method. Penelitian diawali dengan adanya masalah, kajian teori, perumusan hipotesis, dan diakhiri 
dengan pembuktian/uji empiris.

4) Prinsip faktual, yaitu bahwa kajian dan pembahasan terbatas pada isi pesan yang tampak/tersurat, bukan persepsi dan perasaan peneliti. Persoalan simpulan analisis menun-jukkan adanya sesuatu yang tersirat dibalik yang tersurat hal itu tidak menjadi persoalan sepanjang semua kegiatan analisis dan pembahasan didasarkan pada isi yang tersurat.

\section{PENERAPAN ANALISIS ISI DALAM PENELITIAN PENDIDIKAN}

Analisis isi dapat diaplikasikan secara luas dalam penelitian pendidikan, misalnya digunakan untuk: (1) menggambarkan kecenderungan (trend) dalam persekolahan melalui pengujian profesional dan/atau publikasi umum; (2) mengetahui pola organisasional (dengan pengujian chart, outline yang disiapkan oleh penyelenggara) pen-didikan; (3) memperlihatkan cara sekolah yang berbeda mengatasi permasalahan yang sama dengan cara yang berbeda; (4) menduga sikap, nilai dan pola budaya dari negara/daerah yang berbeda; (5) membandingkan mitos yang dipercaya oleh masyarakat me-ngenai sekolah dengan hal yang terjadi sebenarnya (dengan mem-bandingkan hasil jajak pendapat yang didapat dari publik/umum dengan literatur yang ditulis oleh guru dan mahasiswa serta karya sekolah lainnya); (6) memperoleh informasi mengenai perasaan guru tentang kerja mereka (dengan meng-analisis tulisan guru tentang kerja mereka); (7) memperoleh beberapa ide tentang cara pengelolaan sekolah (dengan melihat film dan progam TV yang melukiskan hal yang sama).

Analisis isi dapat juga digunakan sebagai pelengkap dari penggunaan metode yang lain. Sikap terhadap wanita yang bekerja, misalnya, dapat di-ung-kap dengan bermacam teknik, seperti angket, wawancara mendalam, observasi, dan/atau analisis isi pada artikel majalah, program TV, koran, film, dan autobiografi tentang pekerja wanita. Analisis isi juga dapat dimanfaatkan untuk memberi wawasan kepada peneliti tentang masalah atau hipotesis yang dapat diuji dengan metode yang tepat.

Banyak manfaat yang dapat diperoleh dengan penerapan metode analisis isi. Pemanfaatan kajian analisis isi bukan hanya untuk mendeskripsikan karakteristik komunikasi, melainkan juga untuk menentukan simpulan tentang sifat komunikator, situasi dan kondisi khalayak, dan konsekuensi dari tindak komunikasi. Subiakto (2006:176--179) menyatakan bahwa kajian analisis isi pernah digunakan dalam mendeskripsikan gaya dan teknik 
propaganda dan komparasi kecenderungan politik antara suatu media dan media lainnya. Lebih lanjut Wimmer dan Dominick (2000:136-138) memaparkan lima manfaat penelitian analisis isi. Kelima manfaat itu adalah sebagai berikut.

\section{Deskripsi Isi Komunikasi (Describing}

\section{Communication Content)}

Analisis isi berperan dalam menggambarkan kecenderungan isi komunikasi, baik komunikasi tulis maupun lisan, disajikan pada media cetak atau pun elektronik. Misalnya, penelitian yang ingin mendeskripsikan gaya komunikasi tokoh pemerintahan pada media massa. Apakah dengan gaya agresif dan menyerang pihak lain, atau submisif, cenderung mengalah dan diam? Apakah pemberitaan konflik politik di media massa bersifat imparsial ataukah partisan? Misalnya juga, penelitian tentang perbedaan makna cantik pada era 1980-an dan era 2000-an dengan cara mem-bandingkan model iklan pada masa 1980-an dengan masa 2000-an, antara lain dengan membandingkan rambutnya: keriting, ikal, lurus, panjang, pendek; kulit model iklan: kuning langsat, kecoklatan, sawo matang, putih, atau hitam.

2. Pengujian Hipotesis Karakteristik Pesan (Testing Hypothesis of Messages Characteristics)
Beberapa peneliti analisis isi melihat korelasi karakteristik tertentu dari komunikator (media publikasi) dengan karakteristik pesan yang dihasilkan. Kenney dan Simpson (1993), contohnya, mengkaji isi liputan pemilihan presiden Amerika Serikat pada 1988, hasilnya menunjukkan bahwa berita yang disajikan Washington Post cukup berimbang dan netral, sementara itu pemberitaan Washington Times cenderung lebih memihak condong kepada Partai Republik. Sementara itu Liebler dan Smith (1997) menyimpulkan bahwa untuk narasumber pemberitaan, baik koresponden berjenis kelamin laki-laki maupun perempuan, lebih memilih narasumber dengan jenis kelamin laki-laki. Lembaga Konsumen Media pada 1999 mengkaji keakuratan pemberitaan politik pada berita utama sembilan media massa cetak besar di Indonesia, hasilnya menunjukkan bahwa Harian Kompas merupakan surat kabar paling akurat dalam memisahkan fakta dan opini dan kelengkapan data (Subiakto,2006:178).

3. Perbandingan Isi Media dengan Realitas (Comparing Media Content to the "Real World')

Analisis isi dapat dimanfaatkan dalam perbandingan pesan yang di-sampaikan media massa dengan keadaan yang sesungguhnya dalam realitas ke-hidupan sehari-hari. Gerbner (1969) misalnya, 
melakukan komparasi antara tindak kekerasan yang ditayangkan media TV dan tindak kekerasan yang terjadi dalam kehidupan nyata; Taylor dan Bang (1997) melakukan komparasi antara tiga kelompok minoritas yang ada dalam iklan majalah di Amerika Serikat dan populasi nyata di masyarakat. Hasilnya menunjukkan bahwa warga minoritas Amerika Latin adalah kelompok yang paling tidak terwakili dalam iklan-iklan mjalah Amerika dibandingkan dengan minoritas lain yang berasal dari Asia atau pun Afrika (Subiakto,2006:178).

\section{Perkiraan Gambaran Kelompok}

Tertentu di Masyarakat (Assessing the Image of Particular Groups in Society)

Beberapa peneliti analisis isi fokus dalam mengkaji gambaran media tentang kelompok minoritas tertentu. Dalam studi tersebut, analisis isi dimanfaatkan untuk mengkaji permasalahan sosial mengenai keberpihakan dan persepsi pada kelompok minoritas, agama dan ras tertentu. Misalnya, meneliti peran dan perilaku orang kulit hitam dalam film-film Amerika. Apakah lebih sering menjadi tokoh yang baik hati, atau pelaku kriminalitas? Hasil penelitian Segar dan Wheeler (1971) menunjukkan bahwa $75 \%$ tokoh utama diperankan oleh warga Amerika berkulit putih, 6\% warga berkulit hitam, dan $19 \%$ kelompok minoritas lain. Taylor dan Stern
(1997) menegaskan, bahwa orang Amerika keturunan Asia di iklan TV Amerika tahun 1990-an, hanyalah sekitar 10\% dari total model iklan yang tampil (Subiakto, 2006:179).

\section{Pendukung Studi Dampak Media Massa}

Analisis isi lazim dipakai untuk sarana dalam memulai studi dampak media massa. Misalnya dalam kajian analisis kultivasi (cultivation analysis). Dalam penelitian ini pesan yang dominan dan topik-topik isi media yang didokumentasikan dengan prosedur yang sistematis dihubungkan dengan kajian lain mengenai khalayak. Penelitian tersebut dilakukan guna mendeskripsikan pengaruh pemberitaan/tayangan media massa terhadap sikapsikap para pengguna fanatik media. Gerbner, Gross, Signorielli, Morgan, dan Jacson Beeck (1979) dalam Subiakto (2006:179) menyimpulkan bahwa pemirsa fanatik (heavy viewers) televisi memiliki kecenderungan takut pada lingkungan sekitar. Studi agenda setting juga merupakan kajian dampak/ efek media yang diawali dengan analisis isi terhadap pesan media; analisis isi dimanfaatkan untuk mendeskripsikan agenda media, lalu dikorelasikan dengan agenda publik berupa hal-hal yang dianggap penting oleh publik (data diperoleh melalui survei).

\section{KATAGORISASI DAN LANGKAH- LANGKAH DALAM ANALISIS ISI}


1. Penentuan Katagori dalam Analisis Isi

Seluruh prosedur yang disebut dalam analisis isi memunyai beberapa karakteristik yang umum. Prosedur ini juga bermacam-macam, bergantung pada tujuan dan ragam komunikasi yang dianalisis. Ada dua prosedur yang mungkin dilakukan. Kedua prosedur itu adalah sebagai berikut.

a. Penentuan katagori sebelum analisis. Penentuan katagori ini didasari pada pengetahuan terdahulu, teori dan/atau pengalaman. Sebagai contoh, penggunaan katagori yang sudah ditetapkan sebelumnya untuk menjabarkan dan mengevaluasi artikel jurnal yang membahas pendidikan studi sosial.

b. Peneliti menentukan katagori selama analisis, karenanya peneliti menjadi sangat familiar dengan informasi deskriptif yang dikumpulkan, ia membiarkan katagori tersebut muncul sebagai analisis yang selanjutnya.

\section{Langkah-Langkah Analisis Isi}

Fraenkel and Wallen (2006: 485491) menjelaskan delapan langkah dalam melakukan penelitian dengan metode analisis isi. Kedelapan langkah itu adalah sebagai berikut.

a) Penentuan Sasaran

1) Tentukan sasaran khusus yang ingin dicapai.

2) Untuk memeroleh informasi deskriptif tentang sebuah topik.
Analisis isi cara yang sangat berguna untuk mendapatkan informasi yang menjabarkan isu atau topik. Sebagai contoh, sebuah analisis isi dalam praktik membesarkan anak dalam negara yang berbeda dapat memberikan informasi deskriptif yang mungkin menuju pada pertimbangan pendekatan yang berbeda dalam masyarakat.

3) Untuk memformulasikan tema yang membantu mengorganisasi dan membuat sense/rasa pada sejumlah besar informasi deskriptif. Tema adalah kode khusus kelompok yang muncul baik selama atau setelah proses pengembangan kode.

4) Untuk mengecek penemuan penelitian lainnya. Analisis isi sangat membantu dalam validasi penemuan sebuah studi yang menggunakan metodologi penelitian lainnya. Misalnya, hasil wawancara dengan profesor perguruan tinggi dan pengajaran mereka dapat diverifikasi dengan melakukan analisis isi pada rencana pembelajaran (lesson plan) mereka.

5) Untuk mendapatkan informasi yang berguna yang menyangkut masalah pendidikan. Analisis isi dapat membantu guru merencanakan aktivitas yang membantu murid belajar. Sebagai contoh analisis isi 
pada tulisan murid dapat membantu guru menganalisis gramatikal, ejaan, pilihan kata, atau kesalahan stilistika.

6) Untuk mengetes hipotesis. Analisis isi juga dapat digunakan untuk menginvestigasi hubungan yang mungkin atau untuk mengetes ideide. Sebagai contoh, peneliti mungkin menghipotesiskan bahwa buku pelajaran sosial telah berubah dalam derajat yang mereka tekankan pada peranan individu minoritas dalam sejarah negara kita. Analisis isi sebuah sampel teks yang dipublilkasikan selama hampir 20 tahun terakhir akan mengungkapkan jika ini adalah sebuah kasus.

b) Menentukan Unit Analisis

Apakah yang sebenarnya dianalisis? Kata? Frasa? Kalimat? Paragraf? Unit yang akan digunakan untuk melaksanakan dan melaporkan analisis harus dispesifikasi sebelum peneliti memulai analisis.

\section{c) Menentukan Data yang Relevan}

Ketika sudah jelas sasaran dan unit analisisnya, peneliti harus menentukan data (buku teks, majalah, lagu, outline, lesson plan) yang akan dianalisis dan yang relevan dengan sasaran. Hubungan antara isi yang dianalisis dan sasaran studi harus jelas. Salah satu cara untuk membantu memastikan hal ini adalah untuk memiliki pertanyaan penelitian yang spesifik (dan kemungkinan hipotesis) dalam pikiran dan kemudian memilih materi di mana pertanyaan atau hipotesis itu dapat diinvestigasi.

d) Mengembangkan Dasar Pemikiran

Peneliti memerlukan hubungan yang konseptual untuk rnenjelaskan bagaimana data dihubungkan dengan sasaran. Hubungan antara pertanyaan dan isi sering sangat nyata. Di lain waktu, hubungan terlihat sangat tidak nyata dan perlu untuk dijelaskan. Jadi, peneliti yang tertarik dalam perubahan sikap terhadap kelompok tertentu mungkin memutuskan untuk melihat bagaimana mereka diperankan dalam cerita pendek yang ada di majalah yang dipublikasikan dalam waktu yang berbeda. Peneliti harus berasumsi bahwa perubahan dalam peran petugas polisi dalam cerita itu mengindikasi perubahan sikap terhadap mereka.

Banyak analisis isi yang menggunakan bahan yang tersedia, tetapi peneliti juga dapat mengumpulkan data sendiri. Jadi, angket yang terbuka dapat dilaksanakan pada kelompok siswa untuk mendapatkan data mengenai perasaan, pandangan, dan sikap mereka terhadap kurikulum yang baru dikenalkan dan kemudian peneliti menganalisis respon mereka. Wawancara terbuka juga dapat 
dilakukan pada kelompok siswa untuk menilai persepsi mereka pada kekuatan dan kelemahan program konseling sekolah, dan wawancara ini akan dikodekan dan dianalisis.

e) Mengembangkan Rencana Sampling

Sebagai contoh, novel dapat disampelkan pada satu atau lebih level/tingkatan, seperti kata, frasa, kalimat, paragraf, bab, buku, atau pengarang. Program TV dapat disampelkan dengan tipe, saluran, sponsor, produser, atau waktu tayang. Beberapa jenis komunikasi dapat disampelkan pada beberapa tingkatan konsep yang tepat.

Teknik sampling yang paling banyak digunakan dalam analisis isi adalah purposive sampling design. Misalnya, peneliti ingin mendapatkan rekaman wawancara dari beberapa siswa karena mereka semua adalah talenta musisi yang luar biasa.

Teknik sampling acak/random juga dapat digunakan dalam analisis isi. Sebagai contoh, peneliti mungkin memilih random sample pada buku bahasa Indonesia, panduan kurikulum, dan lesson plan yang disiapkan oleh guru sejarah SMA dalam kota, atau kemungkinan lainnya adalah semua nomor lagu Ebiet G. Ade yang direkam dan memilih 50 sampel acak untuk dianalisis. Stratified sampling juga dapat digunakan dalam analisis isi. Sebagai contoh, peneliti tertarik pada peraturan sekolah pada sekolah negeri tertentu. Peneliti dapat memulai dengan mengelompokan sekolah pada area geografis dan satuan pendidikan, kemudian menggunakan random atau sistematis sampling untuk memilih wilayah tertentu. Stratifikasi memastikan bahwa sampel mewakili keadaan luas wilayah dan lokasi. Kemudian pernyataan kebijakan akan didapat dari setiap wilayah dalam sampel untuk dianalisis

Cluster sampling juga dapat digunakan. Pada contoh yang telah dibahas, jika unit analisis menit pertemuan dibandingkan dengan kebijakan formal, menit pada semua pertemuan selama tahun akademik dapat dianalisis. Setiap daerah yang dipilih secara random akan memberikan sekelompok menit pertemuan. Jika menit hanya pada satu atau dua pertemuan dipilih secara acak dari setiap daerah, hal ini akan menjadi contoh dua tahap random sampling.

f) Memformulasikan Kode Katagori

Setelah peneliti menetapkan setepat mungkin aspek isi yang akan diinvestigasi, dia perlu untuk memformulasi katagori yang relevan untuk investigasinya. Katagori harus sangat eksplisit sehingga peneliti lain dapat 
juga memakainya untuk menguji materi yang sama dan memperoleh hasil pokok yang sama, yaitu menemukan frekuensi yang sama dalam setiap katagori.

Sebagai contoh seorang peneliti tertarik dengan ketepatan ilustrasi dan pandangan pengarang tentang perempuan dalam novel. Masalah penelitian yang akan dijawab adalah "Apakah ilustrasi dan persepsi pengarang tersebut netral atau condong berat sebelah? Jika iya, mengapa? Studi analisis ini cocok diterapkan untuk menjawab masalah penelitian tersebut. Langkah pertama yang dilakukan adalah merencanakan cara pemilihan novel yang akan dianalisis. Dalam penelitian ini harus disusun dan dikembangkan katagori yang berhubungan agar dapat diidentifikasi isi novel sesuai dengan tujuan penelitian. Seandainya peneliti memutuskan melihat sosok perempuan dihadirkan dalam novel, langkah pertama yang harus dilakukan adalah memilih sampel/novel; lalu memformulasikan katagorinya: cara penggambaran perempuan, ciri-ciri yang dimiliki, kondisi fisik, emosi dan sifat sosial perempuan; dan identifikasi katagori secara terinci dengan pemberian kode pada setiap unit analisis.

Cara lain untuk menganalisis isi media adalah menggunakan katagori "ruang" dan 'waktu". Misalnya, berapa inci/cm dari halaman koran digunakan untuk pemberitaan demonstrasi maha- siswa menuntut presiden mengundurkan diri? Berapa menit siaran televisi menayangkan demontrasi pegawai honorer menuntut diangkat menjadi pegawai negeri sipil? Berapa ruang atau waktu yang digunakan media massa cetak dan elektronik untuk memberitakan kriminalitas dibandingkan dengan berita dengan topik bukan kriminalitas?

Proses pengembangan katagori yang timbul dari data kadang sangat kompleks. Dalam melakukan analisis isi, peneliti dapat mengkodekan baik isi komunikasi yang nyata maupun yang tersembunyi. Isi komunikasi yang nyata merujuk pada kejelasan isi di permukaan (kata, gambar, dan lain-lain) yang secara langsung dapat diakses oleh mata telanjang atau telinga. Contoh, untuk menentukan apakah rangkaian pelajaran mendorong pengembangan keterampilan berpikir kritis, peneliti dapat benar-benar menghitung jumlah kata yang muncul dalam sasaran pelajaran yang terdaftar di rencana pelaksanaan pembelajaran (RPP) atau kata-kata dan kalimat yang digunakan guru dalam pelaksanaan pembelajaran di kelas. Di lain pihak, isi/makna yang tersembunyi/implisit merujuk pada arti yang mendasari hal yang disebutkan atau yang ditunjukkan. Untuk mendapatkan arti yang mendasar pada rencana pelaksanaan pembelajaran, peneliti dapat membaca keseluruhan RPP atau sampel 
halaman, khususnya yang menggambarkan aktivitas di ruang kelas dan penilaian PR yang akan dikerjakan oleh siswa. Kemudian peneliti membuat penilaian dengan parameter yang telah ditetapkan sebelumnya mengenai derajat/ tingkat pengembangan berpikir kritis dari pembelajaran yang dilaksanakan guru.

g) Validitas dan Reliabilitas

Vadilitas yang sering disebut dengan kesahihan atau ketepatan merujuk pada kualitas data yang dikumpulkan dengan menggunakan intrumen tertentu dapat juga diartikan sebagai derajat ketepatan antara data yang dikumpulkan peneliti dengan data yang sesungguhnya terjadi/ada pada subjek/lokasi penelitian. Dalam analisis isi validitas dapat diperoleh dengan membandingkan isi yang tersurat dengan makna dibalik yang tersurat (tersembunyi atau implisit); atau mencocokkan data yang terkumpul dengan keadaan yang sesungguhnya terjadi pada sumber/subjek yang diteliti; atau mencocokkan data yang terkumpul dengan katagori yang telah disusun sebelumnya; atau membandingkan data

$$
\mathrm{CR}=\frac{2 \mathrm{M}}{\mathrm{N} 1+\mathrm{N} 2} \quad \begin{array}{r}
\text { yang } \\
\text { terkumpul } \\
\text { dengan }
\end{array}
$$

menggunakan satu instrumen dengan hasil dari peng-gunaan instrumen lain; membandingkan hasil yang diperoleh dari seorang pe-ngumpul data/penilai dengan pengumpul data/penilai lain; atau dapat juga dengan membandingkan hasil dari seorang responden/sumber dengan responden/ sumber yang lain tentang satu hal yang sama. Upaya mencocokkan atau mem-bandingkan data tersebut seyogyanya dila-kukan oleh ahli/expert pada bidang yang diteliti sehingga sering disebut dengan validitas ahli atau expert judgement.

Reliabilitas merupakan indeks yang menunjukkan keterandalan/dapat dipercaya suatu instrumen (katagorisasi). Pengujian reliabilitas dapat dilaksanakan dengan cara melakukan pencatatan pada saat pengumpulan data dalam kartu data atau lembar koding sesuai dengan katagorisasi yang ditentukan. Setelah itu penilai ahli melakukan pengujian reliabilitas terhadap katagori yang sudah ditentukan seperti yang dikerjakan peneliti (dengan cara yang sama). Langkah berikutnya adalah membandingkan hasil yang diperoleh dari peneliti dan dari penilai ahli untuk mengetahui data yang disetujui oleh keduanya. Perhitungan reliabel tidaknya katagorisasi data dilakukan dengan menggunakan formula yang disampaikan oleh R. Holsty dalam Wimmer and Dominick (1997:128), yaitu:

Keterangan:

C.R. = nilai koefisien reliabilitas 
$\mathrm{M}=$ Jumlah data yang disepakati

kedua pengumpul data/pengode

N1, N2 = Jumlah data yang terkumpul dari kedua pengode/pengumpul data

Meskipun belum ada standar mutlak dari reliabilitas, Wimmer dan Dominick (1997:128) menyatakan jika nilai CR di atas 0,70 data tersebut dapat diterima sebagai data penelitian yang reliabel.

h) Analisis Data

Penghitungan adalah sifat penting bagi beberapa analisis isi. Setiap waktu sebuah unit dalam katagori yang berhubungan dapat "dihitung". Jadi, hasil akhir pada proses pengkodean pasti nomor. Sangat jelas bahwa penghitungan frekuensi beberapa kata, frasa, simbol, gambar, atau isi yang nyata lainnya memerlukan penggunaan nomor.

Misalnya, dilakukan analisis isi pada editorial kebijakan dalam beberapa koran di Indonesia, mula-mula dibuat tabel untuk menentukan jumlah rubrik yang digunakan untuk pengodean editorial.

Tabel Kategori Hasil Penilaian

\begin{tabular}{|c|c|c|c|c|c|c|}
\hline No & Lo & Opla & Jum & Hasi & No. & No. \\
. & kas & $\mathrm{h}$ & lah & 1 & Edit & Edit \\
Me & $\mathrm{i}$ & & Edit & Penil & orial & orial \\
dia & & & orial & aian & Yan & Yan \\
& & & & & $\mathrm{g}$ & $\mathrm{g}$ \\
\hline
\end{tabular}

\begin{tabular}{|c|c|c|c|c|c|c|}
\hline & & & & & $\begin{array}{l}\text { setuj } \\
\mathrm{u} \\
\text { Abo } \\
\text { rsi }\end{array}$ & $\begin{array}{c}\text { tida } \\
\mathrm{k} \\
\text { setuj } \\
\mathrm{u} \\
\text { Abo } \\
\text { rsi }\end{array}$ \\
\hline (1) & (2) & (3) & (4) & (5) & (6) & (7) \\
\hline $\begin{array}{c}00 \\
1\end{array}$ & A & $\begin{array}{l}150 . \\
000\end{array}$ & 29 & 3 & 0 & 1 \\
\hline $\begin{array}{c}00 \\
2\end{array}$ & B & $\begin{array}{c}1.00 \\
0.00 \\
0\end{array}$ & 50 & 3 & 1 & 1 \\
\hline $\begin{array}{c}00 \\
3\end{array}$ & $\mathrm{C}$ & $\begin{array}{l}750 . \\
000\end{array}$ & 45 & 1 & 2 & 0 \\
\hline $\begin{array}{c}00 \\
4\end{array}$ & $\mathrm{D}$ & $\begin{array}{c}2.00 \\
0.00 \\
0\end{array}$ & 75 & 2 & 7 & 0 \\
\hline
\end{tabular}

Kolom pertama berisi kode media yang diteliti, kolom kedua dan ketiga berisi kota lokasi media dan jumlah oplah, kolom keempat mendata jumlah editorial yang dikodekan/diteliti, kolom kelima berisi hasil penilaian subjektif oleh peneliti pada setiap kebijakan editorial media/koran, dan kolom keenam dan ketujuh mencatat jumlah editorial sesuai dengan katagori.

Kemudian langkah terakhir adalah menganalisis data yang telah ditabulasikan. Seperti pada metode penelitian lainnya, prosedur statistik dekriptif berguna untuk merangkum data dan mem- 
bantu peneliti dalam mengintepretasikan yang telah diungkap. Cara yang umum dipakai untuk mengintepretasikan data analisis isi adalah dengan menggunakan frekuensi dan persentase atau proporsi kejadian khusus pada total kejadian.

Paul W. Mising dalam Bungin (2006:222) menganalisis data dalam penelitian analisis isi yang dilakukannya dengan urutan sebagai berikut.

1. Pemberian kode pada kata, istilah, frasa, dan kalimat yang relevan dengan masalah penelitian, frekuensi kemunculan pada media yang diteliti. Dalam pengodean perlu dicatat konteks munculnya kata/istilah/kalimat itu.

2. Klasifikasi/pengelompokkan terhadap hasil pengodean. Pengelompokkan dilakukan dengan memperhitungkan relasi makna kata/istilah/kalimat dengan tujuan penelitian. Pengelompokkan ini dimaksudkan untuk menyusun katagori dari setiap kelompok.

Mengenai klasifikasi data hasil pengodean, (Krippendorff,1991:35--37) mengemukakan tiga jenis/bentuk klasifikasi hasil pengodean. Ketiga jenis klasifikasi itu adalah sebagai berikut.

1. Isi pragmatis, pengelompokkan tanda/ simbol/lambang yag berupa kata/ istilah/kalimat berdasarkan hubungan sebab-akibat. Misalnya, jumlah kemunculan kata/istilah/kalimat tertentu yang menjadi sebab munculnya sikap menyukai sebuah karya.

2. Isi semantik, pengelompokan data (kata/istilah/kalimat) menurut maknanya. Isi semantik ini terdiri atas tiga jenis: (1) penunjukkan (designation), mendeskripsikan frekuensi objek tertentu (orang, benda, kelompok, atau konsep) dirujuk, (2) pendaftaran (attributions), mendeskripsikan frekuensi karakter tertentu dirujuk (misalnya referensi kepada kebohongan, perundungan, kenakalan, dan kejahatan); dan (3) pernyataan (assertions), mendeskripsikan frekuensi objek tertentu dikarakteristikkan secara khusus. Analisis ini secara umum disebut analisis tematik. Misalnya, referensi terhadap perilaku mencontek di kalangan pelajar dan mahasiswa sebagai pecundang atau pembohong dan pencuri.

3. Sarana tanda (sign-vehicle), yaitu pengelompokkan data penelitian berdasarkan sifat psikofisik dari tanda (kata/istilah/ kalimat), misalnya frekuensi kemunculan kata kognitif, afektif, psikomotor, cerdas, cakap, dan cantik muncul.

4. Analisis hubungan satuan dan katagori untuk mengungkapkan makna/arti dan tujuan komunikasi. 
Hasil analisis tersebut kemudian dipaparkan dalam bentuk laporan penelitian.

Tahapan penelitian yang sedikit berbeda disampaikan oleh Subiakto (2006:181--185) yang menyatakan bahwa langkah-langkah analisis isi meliputi: (1) merumuskan masalah penelitian, (2) menyusun kerangka kerja teoretis, (3) penentuan perangkat metodologi, (4) penentuan teknik analisis data, dan (5) pembahasan hasil penelitian yang merupakan intepretasi terhadap terhadap hasil analisis data. Berikut ini dipaparkan satu per satu secara singkat.

\section{Penetapan Rumusan Masalah}

Seperti halnya penelitian yang lain, analisis isi juga diawali dengan penetapan masalah yang akan diteliti. Masalah merupakan titik tolak dari seluruh kegiatan penelitian. Sebelum memilih, menetapkan, dan merumuskan masalah, terlebih dahulu dipaparkan arti pentingnya variabel penelitian disertai gambaran kondisi ideal dan kondisi nyata pada aaat penelitian akan dilakukan. Dari paparan itu akan dijumpai adanya kesenjangan antara kondisi ideal dan kondisi nyata dari variabel yang diteliti. Berdasarkan hal itulah, peneliti melakukan identifikasi seluruh masalah dari penelitian yang akan dilakukan. Jika permasalahan yang timbul banyak dan luas, peneliti dapat melakukan pembatasan masalah atau menentukan fokus penelitian, lalu fokus permasalahan tersebut disusun rumusan masalah penelitian. Rumusan masalah penelitian,, lazimnya, dalam bentuk pertanyaan. Rumusan masalah yang baik harus menggambarkan variabel penelitian, sifat hubungan antarvariabel, metode penelitian yang digunakan, instrumen pengumpul data, dan teknik analisis data yang akan dipergunakan.

2. Penyusunan Kerangka Berpikir atau Kerangka Kerja Teoretis (Conceptual atau Theoretical Framework)

Setelah jelas masalah yang akan diteliti, selanjutnya disusun kerangka pemikiran atau definisi-definisi konseptual yang berkaitan dengan permasalahan/fenomena yang diteliti. Tingkatan konseptualisasi masalah ini tentu bergantung pada sifat penelitian. Penelitian deskriptif, misalnya, cukup memaparkan definisi konseptual yang disertai dengan unsur-unsur yang akan diteliti sedangkan untuk penelitian eksplanatif selain diungkapkan secara jelas definisi konseptual juga dikemukakan hubungan satu definisi konseptual dengan definisi konseptual yang lain yang akan melahirkan kerangka berpikir dan hipotesis penelitian.

\section{Penetapan Perangkat Metodologi}


Dalam tahapan ini setidak-tidaknya

dijelaskan hal-hal sebagai berikut.

1) Penentuan teknik pengukuran atau prosedur operasionalisasi konsep/ definisi konseptual, berupa penjabaran konsep dalam dalam ukuran tertentu, misalnya berupa katagori-katagori beserta indikator-indikatornya.

2) Penentuaan populasi, sampel, dan teknik sampling. Cara penetapan sampel sama seperti pada metode penelitian survei, perbedaannya kalau survei unit sampelnya individu, tetapi dalam analisis isi adalah teks, pesan, satuan pesan yang ada pada media, atau medianya sendiri. Penetapan sampel dan unit analisis ini bergantung pada tujuan penelitian.

3) Penentuan teknik dan alat pengumpulan data. Teknik pengumpulan data dapat berupa pencatatan, domumentasi, dan observasi dengan instrumen kartu data, lembar pencatatan/lembar pengodean sesuai dengan katagori yang telah ditetapkan. Agar diperoleh data yang akurat, instrumen yang berupa lembar catatan berdasarkan katagori harus diuji reliabilitasnya. Pengujian reliabilitas sangat penting dalam penelitian analisis isi, tujuannya agar katagori yang ditetapkan benar-benar mutual, eksklusif, dan tuntas. Jika peneliti meminta bantuan orang lain sebagai pengumpul data/pengode harus dilakukan pelatihan agar orang tersebut memiliki kemampuan dan pemahaman yang relatif sama dengan peneliti dalam melakukan pengumpulan/pengodean data.

4) Penentuan Teknik Analisis Data

5) Pada bagian ini peneliti hendaknya memilih teknik analisis data yang akan dipakai. Pemilihan teknik analisis data didasarkan pada sifat penelitian tersebut. Teknik analisis data penelitian kuantitatif tentu berbeda dengan penelitian kualitatif. Dalam penelitian yang bersifat eksplanatif kuantitatif setelah ditetapkan teknik analisis data langkah selanjutnya adalah merumuskan hipotesis statistik berdasarkan hipotesis penelitian yang sudah dirumuskan disertai dengan kriteria uji.

6) Untuk penelitian kualitatif Faisal (1990:122) menawarkan lima teknik analisis data, yaitu (1) analisis domain, (2) analisis taksonomi, (3) analisis komponen, (4) analisis tema budaya, dan (5) analisis komparasi konstan.

7) Analisis domain (domain analysis) lazim digunakan untuk memeroleh gambaran atau pengertian yang bersifat umum dan relatif menyeluruh tentang hal-hal yang tercakup dalam fokus/permasalahan penelitian. Hasilnya berupa pengetahuan/pengertian 
pada tingkat "permukaan" tentang berbagai domain atau katagori konseptual (katagori-katagori simbolis yang mencakup atau mewadahi sejumlah katagori atau simbol lain). Dalam melakukan analisis domain Spradley dalam Faisal (1990:91--92) menyatakan perlunya penelusuran hubungan semantis yang bersifat universal (universal semantic relationship), yang terdiri atas sembilan relasi semantik yang terdiri atas jenis (strict inclution), ruang (spatial), sebab-akibat (cause-effect), rasional/alasan (rationale), lokasi tindakan (location for action), cara ke tujuan (means-end), fungsi (function), urutan (sequence), dan atribut/ karakteristik (atribution).

a. Analisis taksonomi (taxonomic analysis) merupakan kelanjutan dari analisis domain. Analisis taksonomi lebih rinci dan mendalam dari analisis domain dan difokuskan pada domaindomain tertentu yang sangat bermanfaat dalam upaya menggambarkan fenomena/fokus penelitian. Misalnya, kita memfokuskan analisis pada domain "peranan/fungsi guru bahasa Indonesia." Pada analisis domain, misalnya, diketahui bahwa guru bahasa Indonesia memiliki peranan (1) mengelola pembelajaran bahasa di kelas, (2) mengelola kegiatan kesiswaan pada bidang bahasa dan sastra, (3) membantu tugas-tugas administrasi, khususnya yang menyangkut peggunaan bahasa Indonesia yang baik dan benar, dan (4) menjadi teladan penggunaan bahasa Indonesia yang baik dan benar baik secara lisan maupun tertulis Pada analisis taksonomi domain, domaindomain terpilih dirinci lagi sedemikian rupa, termasuk struktur di dalamnya (bagian-bagian dari masing-masing fungsi), tetapi arah perincian dan pendalaman tetap pada "peranan atau fungsi", bukan pada pola/tipe hubungan semantis. Jadi, pada analisis taksonomis yang ditunjukkan adalah struktur internal masing-masing domain dengan mengorganisasikan atau mengelompokkan elemen-elemen yang sama pada suatu domain (Faisal,1990:102).

8) Analisis komponensial (componential analysis) juga berdasarkan analisis domain. Pada analisis komponensial diorganisasikan perbedaan/pertentangan antarelemen dalam satu domain. Analisis komponensial baru dapat dilakukan setelah terkumpul data berupa fakta/informasi yang cukup melalui wawancara dan/atau peng-amatan untuk melacak perbedaan/pertentangan di antara warga suatu domain. Perbedaan/pertentangan tersebut oleh 
peneliti dicarikan dimensi-dimensi yang dapat mewadahinya.

9) Discovering cultural themes 'analisis tema kultural' (selanjutnya disebut analisis tema) merupakan upaya mencari keterkaitan yang menyatukan/ memadukan lintas domain yang ada. Keterkaitan tersebut antara lain berupa konsep seperti values, value orientations, core values, core symbols, premises, ethos, eidos, world view, dan cognitif orientation (Spradley, 1986:186). Gagasan analisis tema bertumpu pada praanggapan bahwa keseluruhan itu lebih daripada sekadar jumlah bagian-bagian (Faisal,1990:106)

10) Analisis komparasi konstan (constant comparative analysis) bermaksud mengembangkan teori berdasarkan data yang terkumpul. Pada bagian ini analisis dipusatkan pada penggambaran yang rinci mengenai sifat atau ciri-ciri dari data yang dikumpulkan. Setelah deskripsi yang akurat mengenai suatu fenomena ditemukan, peneliti menghipotesiskan korelasi di antara gejalagejala yang ada lalu diuji dengan memanfaatkan data yang terkumpul. Berdasarkan akumulasi data tersebut (yang mengindikasikan hubungan yang dihipotesiskan) dirumuskan pernyataanpernyataan teoretis yang lebih umum atau sering diistilahkan dengan grounded theory (Martin dan
Turner,1986:142--143 dalam Faisal, 1990:108).

11) Analisis Data

a. Pada bagian ini data diolah dengan teknik yang sudah ditentukan, jika penelitian bersifat eksplanatif kuantitatif pada tahap ini dilakukan pengujian hipotesis statistik, tanpa melakukan tafsiran berdasarkan teori atau hal-hal lain di luar data yang dikumpulkan. Akan tetapi, jika penelitiannya bersifat kualitatif dapat dipilih salah satu dari lima jenis teknik analisis data yang dikemukakan Faisal (1990:122) di atas.

12) Interpretasi Data

a. Pada bagian ini dibahas/didiskusikan hasil analisis data dengan memberi interpretasi sesuai dengan kerangka berpikir atau kerangka teoretis yang sudah ditentukan pada bagian pada bagian awal Untuk penelitian eksplanatif, pada bagian ini pembahasan dan interpretasi yang dilakukan bertujuan untuk menarik simpulan yang mendukung hipotesis teoretik. Disamping itu, perlu juga disampaikan alternatif penyempurnaan penelitian sejenis pada masa yang akan datang secara akademis, praktis, atau teknis. Pada dasarnya interpretasi data adalah upaya peneliti menarik simpulan ber-dasarkan hasil/temuan penelitian dan analisis 
data empiris dikembalikan ke level konseptual. Di sini ada proses abstraksi atau konseptualisasi yang dilakukan oleh peneliti ter-hadap hasil analisis data.

\section{KEUNTUNGAN DAN KERUGIAN ANALISIS ISI}

Seperti yang kita sebutkan sebelumnya, banyak yang kita ketahui didapat tidak melalui interaksi langsung, tetapi melalui buku, koran, dan hasil karya manusia lainnya. Keuntungan terbesar analisis isi adalah kerendahhatian. Peneliti dapat "mengamati" tanpa "diamati” karena isi yang dianalisis tidak dipengaruhi oleh kehadiran peneliti. Informasi yang mungkin sulit, bahkan mustahil, untuk diperoleh melalui observasi langsung atau cara lainnya, dapat diperoleh melalui analisis buku, teks berita, atau alat komunikasi lainnya, tanpa penulis atau penerbit merasa sedang diteliti. Keuntungan lainnya, yaitu hal ini benar-benar sangat berguna sebagai alat untuk menganalisis data wawancara dan observasi.

Keuntungan analisis isi yang ketiga adalah bahwa peneliti dapat menyelidiki catatan atau dokumen untuk mendapatkan beberapa perkiraan pada kehidupan sosial

3. karena karena belum tentu semua media yang dipilih secara acak memberitakan kerusuhan. yang terdahulu. Analisis isi tidak dibatasi oleh ruang dan waktu untuk mempelajari kejadian sekarang.

Keuntungan yang keempat tumbuh dari fakta bahwa logistik analisis isi relatif sederhana dan ekonomis --mengenai waktu dan sumber-- dibandingkan dengan metode penelitian lainnya terutama jika sumber datanya adalah teks yang siap untuk diakses, seperti koran, laporan, buku, jurnal berkala, dan novel.

Terakhir, Karena data sangat tersedia dan hampir selalu dapat dikembalikan jika dipandang perlu, analisis isi mengizinkan replikasi studi oleh peneliti lainnya. Bahkan Program TV yang langsung dapat direkam dan diulang untuk dianalisis pada waktu lain.

Kekurangan analisis isi yang terpenting adalah sebagai berikut.

1. Analisis isi sebatas meneliti pesan eksplisit, sesuatu yang implisit/tersirat dari suatu pesan tidak menjadi fokus perhatian dari analisis isi.

2. Sulit mendapatkan media atau lokasi memeroleh pesan yang sesuai dengan masalah penelitian. Misalnya, penelitian tentang kerusuhan, hampir tidak mungkin menetapkan sampel secara acak sederhana atau acak sistematis

4. Isi komunikasi tidak selalu merefleksikan fakta, kadang-kadang ada upaya pembelokan makna simbol yang 


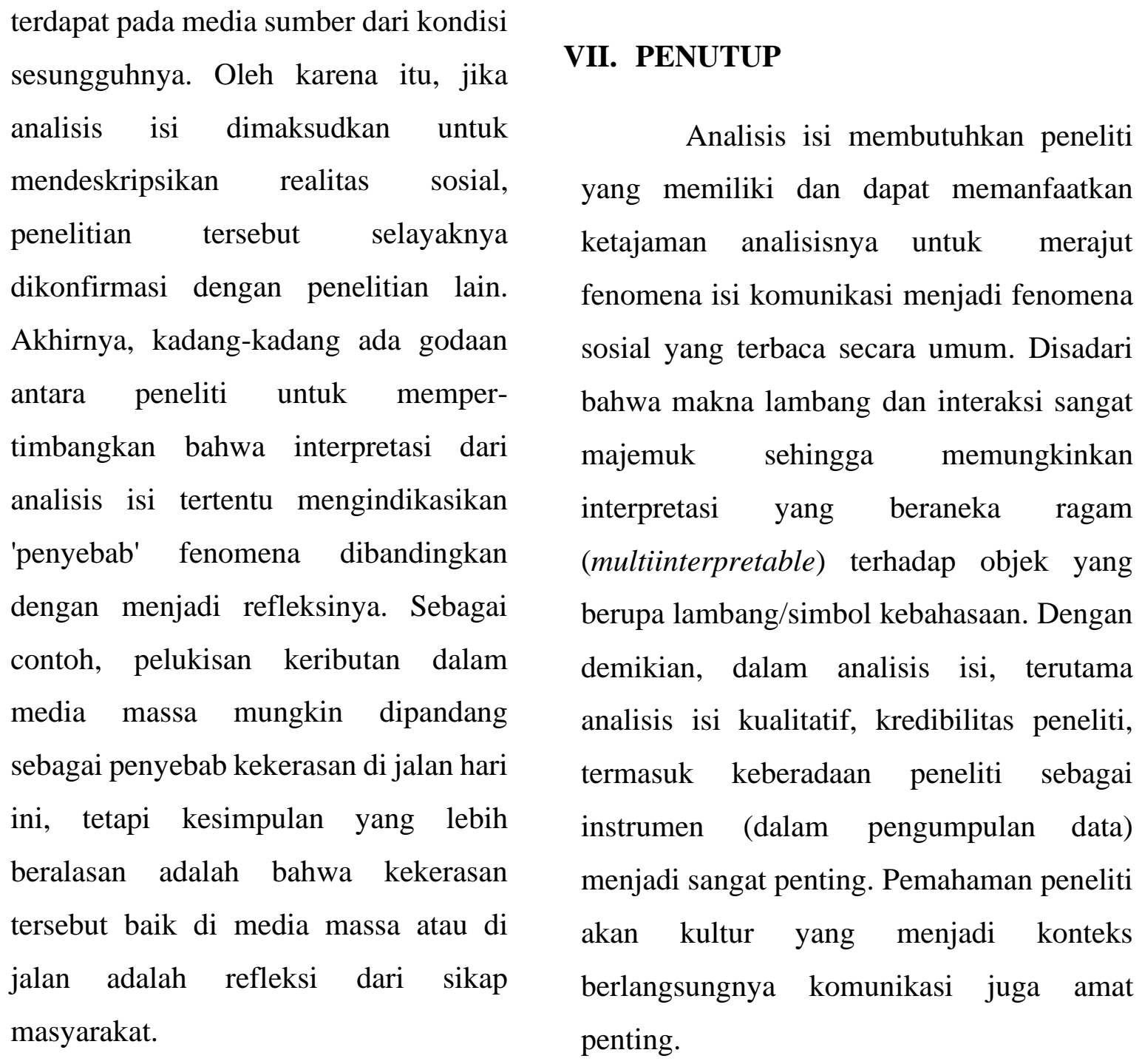

\section{DAFTAR RUJUKAN}

Berger, Arthur Asa. (2000). Media and Communication Research, Methods an Introduction to Qualitative and Quantitative Approaches. New York: Sage Publication.

Bungin, Burhan (Ed.). (2006). Metode Penelitian Kualitatif: Aktualisasi Metodologis ke Arah Ragam Varian Kontemporer. Jakarta: PT RajaGrafindo Persada.

Faisal, Sanafiah. (1990). Penelitian Kualitatif: Dasar-Dasar dan Aplikasi. Malang: YA3.

Fraenkel, Jack R. dan Norman E. Wallen. 2006. How to Design and Evaluate Research in Education, Sixth Edition. New York: Mc Graw-Hill. 
Ida, Rachmah.(2006). "Ragam Penelitian Isi Media Kuantitatif dan Kualitatif”. Dalam Burhan Bungin (Ed.).2006. Metode Penelitian Metode Penelitian Kualitatif: Aktualisasi Metodologis ke Arah Ragam Varian Kontemporer. Jakarta: PT RajaGrafindo Persada.

Krippendorff, Klaus. (1991). Analisis Isi, Pengantar Teori, dan Metodologi. Jakarta: Rajawali Press.

Muhajir,Nung. (2000). Metodologi Penelitian Kualitatif. Edisi IV. Yogyakarta: Rake Sarasin.

Richard, Budd, et all.(1967). Content Analysis of Communication. New York: The Mac Millan Company.

Spradley, James F. (1986). The Ethnographic Interview. New York: Holt, Rinehart and Winston Subiakto, Henry.(2006). “Analisis Isi Media, Metode, dan Pemanfaatannya. Dalam Burhan Bungin (Ed.).2006. Metode Penelitian Metode Penelitian Kualitatif: Aktualisasi Metodologis ke Arah Ragam Varian Kontemporer. Jakarta: PT RajaGrafindo Persada.

Wimmer, Roger D. Dan R. Josep Dominick.(2000). Mass Media Reasearch, Sixth Edition. New York: Wadsworth Publishing Company. 